\title{
Antimony (V) Oxide Adsorbed on a Silica-Zirconia Mixed Oxide Obtained by the Sol-Gel Processing Method: Preparation and Acid Properties
}

\author{
Galina Zaitseva ${ }^{b}$ and Yoshitaka Gushikem ${ }^{*, a}$ \\ ${ }^{a}$ Instituto de Química, Universidade Estadual de Campinas, CP 6154, 13083-970 Campinas - SP, Brazil \\ ${ }^{b}$ Institute of Sorption and Endoecology Problems, Kiev, 252680 Ukraine
}

\begin{abstract}
A preparação, o grau de dispersão, estabilidade térmica e a acidez de Lewis e de Brфnsted do óxido de antimônio (V) adsorvido sobre $\mathrm{SiO}_{2} / \mathrm{ZrO}_{2}$, preparado previamente pelo processo sol-gel, são descritas neste trabalho. Amostras de $\mathrm{SiO}_{2} / \mathrm{ZrO}_{2} / \mathrm{Sb}_{2} \mathrm{O}_{5}$ de composições (\% em massa): (a) $\mathrm{Zr}=$ $8,1 \mathrm{e} \mathrm{Sb}=6,3$; (b) $\mathrm{Zr}=11,4 \mathrm{e} \mathrm{Sb}=11,4$, foram preparadas. As imagens de microscopia eletrônica de varredura conectada a um espectrômetro de energia dispersiva de raios X mostraram que os metais, $\mathrm{Zr}$ e Sb, estão homogeneamente dispersos em ambas as matrizes. Os padrões de difração de raios X de $\mathrm{SiO}_{2} / \mathrm{ZrO}_{2} / \mathrm{Sb}_{2} \mathrm{O}_{5}$ aquecido a diversas temperaturas mostraram que até $1023 \mathrm{~K}$ a amostra apresentou-se amorfa. Em $1273 \mathrm{~K}$ a formação da fase cristalina $\mathrm{ZrO}_{2}$ (baddeleita) foi observada e elevando-se a temperatura a $1573 \mathrm{~K}$, as fases cristalinas de $\mathrm{SiO}_{2}$ (cristobalita) e possivelmente de $\mathrm{ZrO} / \mathrm{Sb}_{2} \mathrm{O}_{5}$ foram observadas. Utilizando a piridina como sonda molecular, sítios ácidos de Br申nsted do sólido $\mathrm{SiO}_{2} / \mathrm{ZrO}_{2} / \mathrm{Sb}_{2} \mathrm{O}_{5}$, aquecido até $523 \mathrm{~K}$, mostraram ser bastante estáveis.
\end{abstract}

The preparation, degree of dispersion, thermal stability and Lewis and Brfnsted acidity of antimony $(\mathrm{V})$ oxide adsorbed on $\mathrm{SiO}_{2} / \mathrm{ZrO}_{2}$ mixed oxide, previously prepared by the sol-gel processing method, are described herein. The samples $\mathrm{SiO}_{2} / \mathrm{ZrO}_{2} / \mathrm{Sb}_{2} \mathrm{O}_{5}$, with compositions (in wt \%): (a) $\mathrm{Zr}=$ 8.1 and $\mathrm{Sb}=6.3$; (b) $\mathrm{Zr}=14.9$ and $\mathrm{Sb}=11.4$, were prepared. Scanning electron microscopy images connected to a X-ray energy dispersive spectrometer showed that both metals, $\mathrm{Zr}$ and $\mathrm{Sb}$, were highly dispersed in the matrices. The X-ray diffraction patterns of $\mathrm{SiO}_{2} / \mathrm{ZrO}_{2} / \mathrm{Sb}_{2} \mathrm{O}_{5}$ heated at different temperatures showed that, up to $1023 \mathrm{~K}$, the matrix was amorphous. At $1273 \mathrm{~K}$ a crystalline phase of $\mathrm{ZrO}_{2}$ (baddeleyite) was observed and raising the temperature to $1573 \mathrm{~K}$, crystalline phases of $\mathrm{SiO}_{2}$ (cristobalite) and presumably of $\mathrm{ZrO}_{2} / \mathrm{Sb}_{2} \mathrm{O}_{5}$ were observed. Using pyridine as a molecular probe, $\mathrm{Br}$ nnsted acid sites on the $\mathrm{SiO} / \mathrm{ZrO} / \mathrm{Sb}_{2} \mathrm{O}_{5}$ matrix, heat treated up to $523 \mathrm{~K}$, were shown to be very stable.

Keywords: sol-gel method, silica-zirconia-antimony mixed oxide, Brфnsted and Lewis acid sites

\section{Introduction}

Antimony oxide, $\mathrm{Sb}_{2} \mathrm{O}_{5}$, as amorphous or crystalline phases, is normally obtained as a fine powder presenting low mechanical and thermal resistance. ${ }^{1,2}$ limiting its use when a rigid and porous matrix is required. Since the oxide presents good acid properties and to overcome this problem, $\mathrm{Sb}_{2} \mathrm{O}_{5}$ has been obtained in a highly dispersed form by the grafting reaction of $\mathrm{SbCl}_{5}$ on a $\mathrm{SiO}_{2}$ surface from a non aqueous solvent. ${ }^{3}$ The material obtained $\mathrm{SiO}_{2} /$ $\mathrm{Sb}_{2} \mathrm{O}_{5}$, combined the acid properties of the antimony oxide with the mechanical and thermal resistance of the $\mathrm{SiO}_{2}$

* e-mail: gushikem@iqm.unicamp.br matrix. The oxide is attached to the surface by $\mathrm{Si}-\mathrm{O}-\mathrm{Sb}$ bond formation. ${ }^{3}$ However, the use of the material has been limited to neutral aqueous solutions because antimony oxide is leached off the surface, due to the easy hydrolysis of the $\mathrm{Si}-\mathrm{O}-\mathrm{Sb}$ bond in acid solution.

An alternative way to obtain chemically stable $\mathrm{Sb}_{2} \mathrm{O}_{5}$ is to adsorb $\mathrm{Sb}(\mathrm{V})$ on a binary mixed oxide matrix obtained by the sol-gel processing method. ${ }^{4}$ This procedure has been used in order to obtain $\mathrm{Sb}_{2} \mathrm{O}_{5}$ dispersed on a $\mathrm{SiO}_{2} / \mathrm{TiO}_{2}$ matrix, rendering the antimony oxide practically insoluble in an acid solution due to the formation of the new titanium (IV) antimonate phase.

The use of the mixed oxide prepared by the sol-gel method is very important because it permits to obtain a 
material where the components are highly and homogeneously dispersed in the matrix. ${ }^{5-13}$ This work describes the procedure to adsorb antimony (V) oxide on $\mathrm{SiO}_{2} / \mathrm{ZrO}_{2}$, previously obtained by the sol-gel processing method, aiming to obtain a homogeneous and poorly soluble zirconium oxide-antimoium oxide phase immobilized on the $\mathrm{SiO}_{2}$ surface. The physical properties of the material, obtained by X-ray diffraction (XRD), X-ray photoelectron spectroscopy (XPS), and scanning electron microscopy (SEM) connected to a X-ray emission analyzer are described. The thermal stability of the Brpnsted solid acid, by using pyridine as the molecular probe, is also described.

\section{Experimental}

\section{Preparation of $\mathrm{SiO}_{2} / \mathrm{ZrO}_{2}$ by the sol gel method}

The silica-zirconia mixed oxides, containing two different compositions of the metal oxide, were prepared by the sol gel method as described elsewhere, with some modifications. ${ }^{14}$ In a reaction flask containing $250 \mathrm{~mL}$ of tetraethylorthosilicate (TEOS, Aldrich; $1.1 \mathrm{~mol}$ ), $14 \mathrm{~mL}$ of aqueous $\mathrm{HCl} 3 \mathrm{~mol} \mathrm{~L}^{-1}$ solution were carefully added and the resulting solution was stirred for $3 \mathrm{~h}$ at $333 \mathrm{~K}$. A solution containing $28 \mathrm{~mL}$ of zirconium tetrabutoxide $\left(\mathrm{ZrBu}_{4}\right.$, Aldrich; $0.061 \mathrm{~mol}$ ) in $80 \mathrm{~mL}$ of dry ethanol was slowly added under an argon atmosphere and the mixture was stirred for $1.5 \mathrm{~h}$. In a second preparation, a mixture containing $69 \mathrm{~mL}$ of $\mathrm{ZrBu}_{4}(0.15 \mathrm{~mol})$ and $80 \mathrm{~mL}$ of dry ethanol was used. About $7 \mathrm{~mL}$ of $3 \mathrm{~mol} \mathrm{~L}^{-1} \mathrm{HCl}$ solution was added dropwise in the first preparation and $17.5 \mathrm{~mL}$ of $3 \mathrm{~mol} \mathrm{~L}{ }^{-1} \mathrm{HCl}$ solution in the second one. The resulting mixtures were allowed to rest for $16 \mathrm{~h}$. The solvents were evaporated by gently heating the mixture at $353 \mathrm{~K}$. The xerogel formed in each preparation was ground and sieved between 200-250 mesh, washed with ethanol in a soxhlet apparatus and then immersed in $0.1 \mathrm{~mol} \mathrm{~L}^{-1} \mathrm{HCl}$ solution for $24 \mathrm{~h}$, filtered and dried under vacuum at $333 \mathrm{~K}$.

Reaction of $\mathrm{SiO}_{2} / \mathrm{ZrO}_{2}$ with $\mathrm{Sb}(\mathrm{V})$

About $20 \mathrm{~g}$ of $\mathrm{SiO}_{2} / \mathrm{ZrO}_{2}$ xerogel was immersed in 50 $\mathrm{mL}$ of an acid solution $(2.5 \mathrm{~mol} \mathrm{~L}-1 \mathrm{HCl})$ of $0.45 \mathrm{~mol} \mathrm{~L}^{-1}$ $\mathrm{Sb}(\mathrm{V})$. The volume was completed to $800 \mathrm{~mL}$ with pure water and the mixture was stirred at $333 \mathrm{~K}$ for $7 \mathrm{~h}$. The solid was filtered, washed with water until the filtrate solution was neutral, and dried at $333 \mathrm{~K}$ in an oven.

\section{Chemical analyses}

Samples of about $0.1 \mathrm{~g}$ of $\mathrm{SiO}_{2} / \mathrm{ZrO}_{2}$ or $\mathrm{SiO}_{2} / \mathrm{ZrO}_{2} / \mathrm{Sb}_{2} \mathrm{O}_{5}$ were treated with a few drops of $40 \% \mathrm{HF}$ solution (v/v) until complete dissolution of the solid. HF was eliminated from the solution with a $\mathrm{HNO}_{3}: \mathrm{HCl}$ mixture $(1: 15 \mathrm{v} / \mathrm{v})$ and the $\mathrm{Sb}$ and $\mathrm{Zr}$ contents were analyzed using atomic absorption spectroscopy on a Perkin Elmer Optima 3000 DV apparatus.

\section{Physical measurements}

The scanning electron micrograph images were obtained from a JEOL JSM T-300 microscope by dispersing the sample on a conducting double-faced tape adhered to an aluminum support. The adhered samples were coated with a thin film of graphite by using the low voltage sputtering technique on a Plasma Science Model LVC 76 apparatus. The X-ray emission analysis was made using a Tracor Northern EDS microprobe.

\section{$U V$-Visible diffuse reflectance spectra (DRS)}

UV-Vis DRS spectra of the samples were obtained by using a UV-VIS-NIR Cary $5 \mathrm{G}$ spectrophotometer. The measurements were carried out using $\mathrm{BaSO}_{4}$ as the blank reference.

X-ray photoelectron spectroscopy (XPS) spectra of the samples were obtained by using an aluminum anode $\left(\mathrm{AlK}_{\alpha}=1486.6 \mathrm{eV}\right)$ at a pressure of $2.66^{\prime} 10^{-5} \mathrm{~Pa}$ on a McPherson ESCA-36 spectrometer. The atomic ratios were estimated by integrating the areas under the peaks using the corresponding Scofileld cross section ${ }^{15}$ for each atomic level involved. The binding energies were calibrated against $\mathrm{C} 1 \mathrm{~s}$ at $284.6 \mathrm{eV}$.

$\mathrm{X}$-ray diffraction patterns were obtained using $\mathrm{CuK} \alpha$ radiation $(\lambda=0.154 \mathrm{~nm})$ at $30 \mathrm{kV}$, current of $20 \mathrm{~mA}$ and a scan rate of $0.033^{0} \mathrm{~s}^{-1}$ (degree in $2 \theta$ ) on a Shimadzu 600 diffractometer.

Specific surface area $\left(\mathrm{S}_{\mathrm{BET}}\right)$ was determined by the BET method by using an ASAP 2010 apparatus from Micromeritics.

The nature of surface acid sites was determined by using pyridine as a molecular probe. Self-supported pressed disks of the sample were previously degassed at $353 \mathrm{~K}$ under vacuum and impregnated with pyridine molecules. The transmission IR spectra were obtained for samples previously heat treated under vacuum at 298, 323, 423 and $473 \mathrm{~K}$. The spectra were recorded at room temperature after 100 cumulative scans with $4 \mathrm{~cm}^{-1}$ resolution. The measurements were carried out on a Bomem MB series spectrophotometer.

\section{Results and discussions}

Table 1 presents the results of the chemical analyses of the samples. The amounts of $\mathrm{Zr}$ (IV) loading in the two 
Table 1. Results of the chemical analyses and specific surface areas for $\mathrm{SiO}_{2} / \mathrm{ZrO}_{2}$ and $\mathrm{SiO}_{2} / \mathrm{ZrO}_{2} / \mathrm{Sb}_{2} \mathrm{O}_{5}$

\begin{tabular}{|c|c|c|c|c|}
\hline Samples & $\mathrm{Zr} / \mathrm{wt} \%$ & $\mathrm{Sb} / \mathrm{wt} \%$ & $\mathrm{~S}_{\mathrm{BET}} / \mathrm{m}^{2} \mathrm{~g}^{-1}$ & Aver. Pore Diameter/nm \\
\hline $\mathrm{SiO}_{2} / \mathrm{ZrO}_{2}(\mathrm{I})$ & $8.4(0.92)$ & - & - & - \\
\hline $\mathrm{SiO}_{2}^{2} / \mathrm{ZrO}_{2}^{2}$ (II) & $15.4(1.68)$ & - & - & - \\
\hline $\mathrm{SiO}_{2} / \mathrm{ZrO}_{2} / \mathrm{Sb}_{2} \mathrm{O}_{5}(\mathrm{I})$ & $8.1(0.89)$ & $6.3(0.52)$ & 590 & 0.73 \\
\hline $\mathrm{SiO}_{2} / \mathrm{ZrO}_{2} / \mathrm{Sb}_{2} \mathrm{O}_{5}$ (II) & $14.9(1.64)$ & $11.4(0.93)$ & 440 & 0.69 \\
\hline
\end{tabular}

( ): mmol of the metal per gram of the matrix.

matrices are 8.4 and $15.4 \mathrm{wt} \%$, corresponding to 0.92 and $1.68 \mathrm{mmol} \mathrm{g}^{-1}$ (amount of zirconium per gram of the sample), respectively. These samples will hereafter be designated as $\mathrm{SiO}_{2} / \mathrm{ZrO}_{2}(\mathrm{I})$ and $\mathrm{SiO}_{2} / \mathrm{ZrO}_{2}(\mathrm{II})$, for the first and second samples, respectively. Incorporation of $\mathrm{Sb}(\mathrm{V})$ on these two matrices were 6.3 and $11.4 \mathrm{wt} \%$ or 0.52 and $0.93 \mathrm{mmol} \mathrm{g}^{-1}$, respectively. These two samples will be hereafter designated as $\mathrm{SiO}_{2} / \mathrm{ZrO}_{2} / \mathrm{Sb}_{2} \mathrm{O}_{5}(\mathrm{I})$ and $\mathrm{SiO}_{2} / \mathrm{ZrO}_{2} / \mathrm{Sb}_{2} \mathrm{O}_{5}$ (II). $\mathrm{The} \mathrm{Sb} / \mathrm{Zr}$ mol ratios in both samples are nearly the same, 0.58 and 0.57 , respectively. These values suggest that incorporation of $\mathrm{Sb}(\mathrm{V})$ onto the $\mathrm{SiO}_{2} / \mathrm{ZrO}_{2}$ matrices arises from the interaction of the metal ion with the surface $\mathrm{Zr}(\mathrm{IV})$. We may suppose that the reaction can be described by the following reaction:

$\mathrm{n} \equiv \mathrm{ZrOH}+\mathrm{Sb}(\mathrm{OH})_{5} \rightarrow(\equiv \mathrm{ZrO})_{\mathrm{n}} \mathrm{Sb}(\mathrm{OH})_{5-\mathrm{n}}+\mathrm{nH}_{2} \mathrm{O}$

where $\equiv \mathrm{ZrOH}$ stands for hydrated zirconium oxide bonded to the $\mathrm{SiO}_{2}$ surface. This supposition is strongly supported by the fact that $\mathrm{Sb}(\mathrm{V})$ does not form stable $\mathrm{Si}$-O-Sb bonds with $\equiv \mathrm{SiOH}$ on the $\mathrm{SiO}_{2}$ surface at low $\mathrm{pH}$, since it is easily hydrolyzed. ${ }^{3}$ The solubility of $\mathrm{Sb}(\mathrm{V})$ in acid solution was negligible, $\sim 10^{-6} \mathrm{~mol}$ per gram of the material, determined by shaking the $\mathrm{SiO}_{2} / \mathrm{ZrO}_{2} / \mathrm{Sb}_{2} \mathrm{O}_{5}$ samples in $0.1 \mathrm{~mol} \mathrm{~L}^{-1}$ $\mathrm{HCl}$ solution for $24 \mathrm{~h}$ at $298 \mathrm{~K}$.

The specific surface area, $\mathrm{S}_{\mathrm{BET}}$, for $\mathrm{SiO}_{2} / \mathrm{ZrO}_{2} / \mathrm{Sb}_{2} \mathrm{O}_{5}$ is smaller for the sample with the higher amount of antimony loading, $590 \mathrm{~m}^{2} \mathrm{~g}^{-1}$ for (I) and $440 \mathrm{~m}^{2} \mathrm{~g}^{-1}$ for (II) and the average pore diameters are 0.73 and $0.69 \mathrm{~nm}$, respectively.

\section{$U V$-vis DRS}

The UV-vis DRS spectra of $\mathrm{SiO}_{2} / \mathrm{ZrO}_{2}$ and $\mathrm{SiO}_{2} / \mathrm{ZrO}_{2} /$ $\mathrm{Sb}_{2} \mathrm{O}_{5}$ samples are shown in Figure 1. The band maxima for $\mathrm{SiO}_{2} / \mathrm{ZrO}_{2}$ for the samples with $8.4 \mathrm{wt} \%$ (Figure $1 \mathrm{~b}$ ) and 15.4 wt\% (Figure 1a) loadings of $\mathrm{ZrO}_{2}$ are observed in both cases at near $228 \mathrm{~nm}$, which correspond to the oxygen to metal charge transfer transition of $\mathrm{Zr}(\mathrm{IV})$. Upon $\mathrm{Sb}(\mathrm{V})$ loading, the band maxima shift to the higher energy region, near $200 \mathrm{~nm}$ (Figures 1c and 1d). For bulk phase $\mathrm{ZrO}_{2}$, this band maximum is observed between $230-240 \mathrm{~nm} .{ }^{16,17}$ The band shift to a lower wavelength region is normally

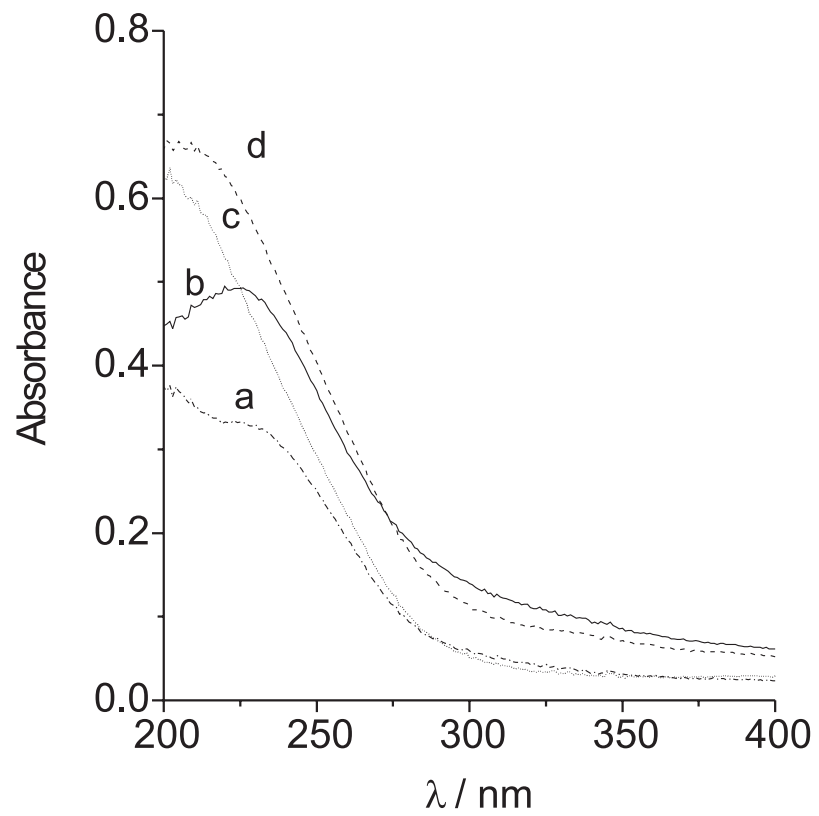

Figure 1. UV-vis DRS of: (a) $\mathrm{SiO}_{2} / \mathrm{ZrO}_{2}$ (II); (b) $\mathrm{SiO}_{2} / \mathrm{ZrO}_{2}$ (I); (c) $\mathrm{SiO}_{2} / \mathrm{ZrO}_{2} / \mathrm{Sb}_{2} \mathrm{O}_{5}$ (II); (d) $\mathrm{SiO}_{2} / \mathrm{ZrO}_{2} / \mathrm{Sb}_{2} \mathrm{O}_{5}$ (I).

associated with a high dispersion of $\mathrm{Zr}(\mathrm{IV})$ in the matrices, with formation of smaller particles. This may occur, in our case, due to the reaction of the immobilized $\mathrm{Zr}(\mathrm{IV})$ with $\mathrm{Sb}(\mathrm{V})$, as described in reaction (1), resulting a new highly dispersed zirconium-antimonate phase.

\section{XPS results}

Table 2 lists the binding energy (BE) values and the atomic ratios of interest. The $\mathrm{Zr}_{5 / 2} \mathrm{BE}$ are observed at ca. $183 \mathrm{eV}$ in $\mathrm{SiO}_{2} / \mathrm{ZrO}_{2}$ and $\mathrm{SiO}_{2} / \mathrm{ZrO}_{2} / \mathrm{Sb}_{2} \mathrm{O}_{5}$, a value which is slightly higher than that for bulk $\mathrm{ZrO}_{2}$, observed at 182.2 $\mathrm{eV} .{ }^{18}$ This increase of the $\mathrm{BE}$ is related with stronger $\mathrm{Zr}-\mathrm{O}$ bond polarization ${ }^{19}$ due to the interaction of $\mathrm{Zr}$ with both the surface $\equiv \mathrm{SiOH}$ and with $\mathrm{Sb}(\mathrm{V})$. For both samples the $\mathrm{Sb}_{3 / 2} \mathrm{BE}$, in comparison with that of bulk phase $\mathrm{Sb}_{2} \mathrm{O}_{5}$ observed at $540.2 \mathrm{eV},{ }^{20}$ did not show any significant change. On the surface, at the depth distance probed by XPS, the $\mathrm{Zr} / \mathrm{Si}$ atomic ratios are 0.088 and 0.21 for $\mathrm{SiO}_{2} / \mathrm{ZrO}_{2}$ (I) and (II), respectively. These values roughly agree with the 
Table 2. Binding Energies (in eV) for $\mathrm{SiO}_{2} / \mathrm{ZrO}_{2}$ and $\mathrm{SiO}_{2} / \mathrm{ZrO}_{2} / \mathrm{Sb}_{2} \mathrm{O}_{5}$

\begin{tabular}{|c|c|c|c|c|c|}
\hline Samples & $\mathrm{Sb} 3 \mathrm{~d}_{3 / 2}$ & $\mathrm{Zr} 3 \mathrm{~d}_{5 / 2}$ & Si2p & $\mathrm{Zr} / \mathrm{Si}^{*}$ & $\mathrm{Sb} / \mathrm{Si}^{*}$ \\
\hline $\mathrm{SiO}_{2} / \mathrm{ZrO}_{2}(\mathrm{I})$ & & 183.0 & 102.9 & & \\
\hline $\mathrm{SiO}_{2}^{2} / \mathrm{ZrO}_{2}(\mathrm{II})$ & & 183.0 & 102.8 & & \\
\hline $\mathrm{SiO}^{2} / \mathrm{ZrO} / \mathrm{Sb}_{2} \mathrm{O}_{-}$(I) & 540.1 & 182.8 & 103.2 & 0.074 & 0.23 \\
\hline $\mathrm{SiO}_{2} / \mathrm{ZrO}_{2} / \mathrm{Sb}_{2} \mathrm{O}_{5}$ (II) & 539.8 & 183.0 & 102.6 & 0.27 & 0.25 \\
\hline $\mathrm{SiO}_{2}$ & & & 103.3 & & \\
\hline $\mathrm{ZrO}_{2}^{2}{ }^{\mathrm{a}}$ & & 182.2 & & & \\
\hline $\mathrm{Sb}_{2} \mathrm{O}_{5}^{\mathrm{b}}$ & 540.2 & & & & \\
\hline
\end{tabular}

$* \mathrm{Zr} / \mathrm{Si}$ and $\mathrm{Sb} / \mathrm{Si}$ atomic ratios were determined from the ratios of integrated areas under BE peaks of the elements; ${ }^{\mathrm{a}}$ reference $22 ;{ }^{\mathrm{b}}$ reference 20 .

$\mathrm{ZrBu}_{4} / \mathrm{TEOS}$ molar ratios used for preparation of the samples, 0.061 and 0.14 . This correspondence suggests that $\mathrm{Zr}(\mathrm{IV})$ oxide is highly and homogeneously dispersed in both matrices. The $\mathrm{Sb} / \mathrm{Si}$ atomic ratios, for both $\mathrm{SiO}_{2} /$ $\mathrm{ZrO}_{2} / \mathrm{Sb}_{2} \mathrm{O}_{5}$, are practically the same, i.e. 0.23 and 0.25 .

\section{Electron micrographs}

Figure 2a shows the scanning electron microscopy (SEM) image of the $\mathrm{SiO}_{2} / \mathrm{ZrO}_{2} / \mathrm{Sb}_{2} \mathrm{O}_{5}$ with the higher antimony loading and Figures $2 \mathrm{~b}$ and $2 \mathrm{c}$ the corresponding EDS images. The white points in Figures $2 \mathrm{~b}$ and $2 \mathrm{c}$ are due to the metal emission lines $\mathrm{ZrK} \alpha=2.05 \mathrm{keV}$ and $\mathrm{SbL} \alpha=$ $3.6 \mathrm{keV},{ }^{21}$ respectively. The SEM and EDS images show that, within the magnification used, the zirconium (IV) and antimony (V) oxide particles are homogeneously dispersed in the matrices with no detectable segregated phases.

\section{$X$-ray diffraction}

Table 3 lists the main X-ray diffraction peaks (intesities higher than 10) of standard $\mathrm{SiO}_{2}$ (cristobalite) ${ }^{22,23} ; \mathrm{ZrO}_{2}$ baddeleyite ${ }^{22}$ and $\mathrm{Sb}_{2} \mathrm{O}_{5}{ }^{22}$ and the observed peaks for $\mathrm{SiO}_{2} /$

Table 3. Selected X-ray diffraction peaks of standard samples ${ }^{8}$ and those observed for $\mathrm{SiO}_{2} / \mathrm{ZrO}_{2} / \mathrm{Sb}_{2} \mathrm{O}_{5}$

\begin{tabular}{|c|c|c|c|c|c|c|c|}
\hline \multicolumn{2}{|c|}{$\mathrm{SiO}_{2}{ }^{\mathrm{a}}$} & \multicolumn{2}{|c|}{$\mathrm{ZrO}_{2}{ }^{\mathrm{b}}$} & \multicolumn{2}{|c|}{$\mathrm{Sb}_{2} \mathrm{O}_{5}{ }^{\mathrm{c}}$} & \multicolumn{2}{|c|}{$\mathrm{SiO}_{2} / \mathrm{ZrO}_{2} / \mathrm{Sb}_{2} \mathrm{O}_{5}$} \\
\hline $2 \theta$ & Int & $2 \theta$ & Int & $2 \theta$ & Int & & Int \\
\hline & & & & 14.9 & 25 & & \\
\hline \multirow[t]{11}{*}{21.9} & 100 & & & & & 21.9 & 20 \\
\hline & & 28.2 & 100 & & & 28.3 & 60 \\
\hline & & & & 28.7 & 20 & & \\
\hline & & & & 30.0 & 100 & 30.3 & 100 \\
\hline & & 31.5 & 68 & & & 31.4 & 20 \\
\hline & & & & 34.4 & 11 & 34.6 & 15 \\
\hline & & 35.3 & 13 & & & 35.4 & 17 \\
\hline & & & & & & 50.0 & 70 \\
\hline & & 50.2 & 22 & 50.0 & 25 & & \\
\hline & & & & 59.5 & 30 & & \\
\hline & & & & & & 60.2 & 40 \\
\hline
\end{tabular}

"Only peaks having intensities greater than 10 are listed. ref. $22^{\mathrm{a}, \mathrm{b}, \mathrm{c}}$.
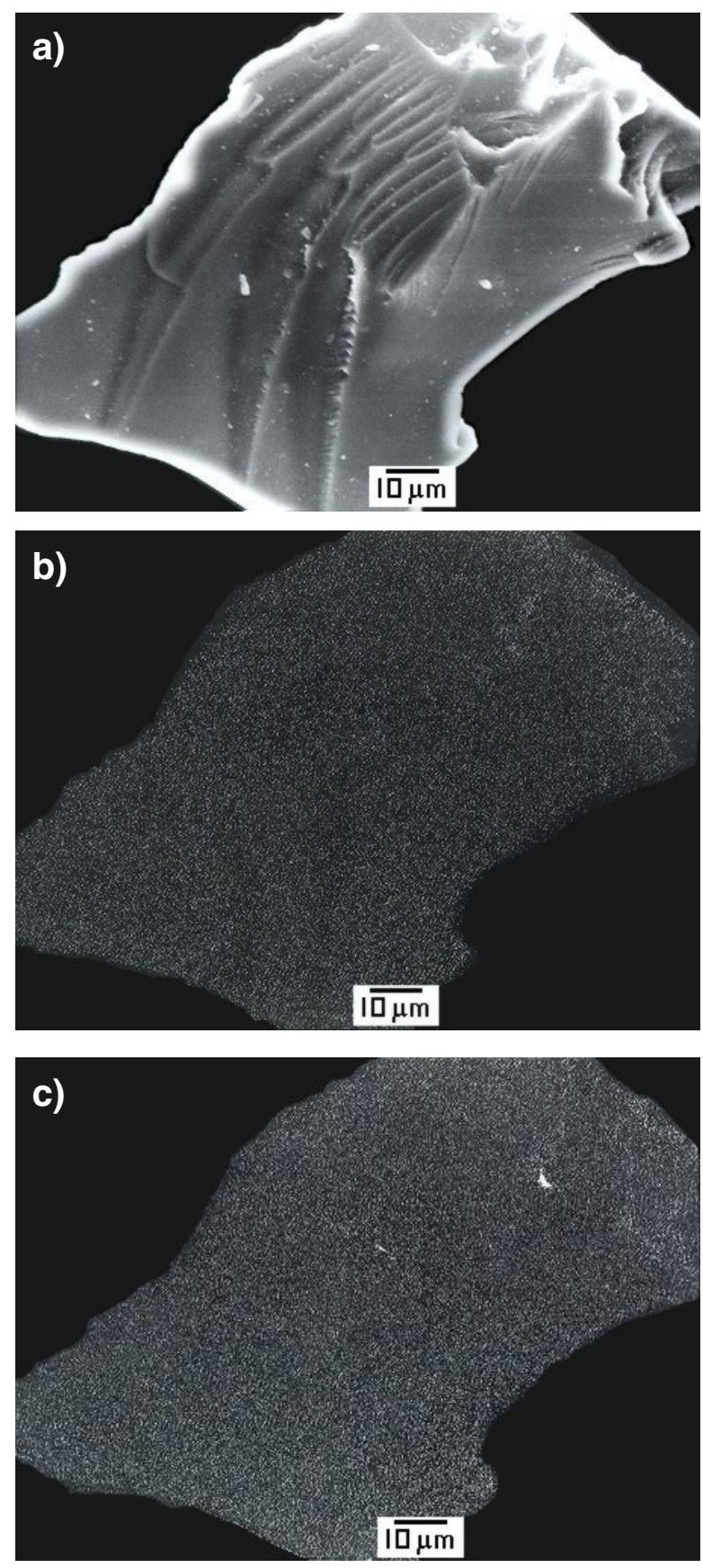

Figure 2. (a) SEM image of $\mathrm{SiO}_{2} / \mathrm{ZrO}_{2} / \mathrm{Sb}_{2} \mathrm{O}_{5}$ (II); The corresponding EDS images for (b) $\mathrm{Zr}$ mapping and (c) Sb mapping. 
$\mathrm{ZrO}_{2} / \mathrm{Sb}_{2} \mathrm{O}_{5}$. Figures $3 \mathrm{a}$ to $3 \mathrm{~d}$ shows the XRD patterns for $\mathrm{SiO}_{2} / \mathrm{ZrO}_{2} / \mathrm{Sb}_{2} \mathrm{O}_{5}$ samples heat treated from 773 up to 1573 $\mathrm{K}$. For the material heated at 773 (3a) and $1023 \mathrm{~K}(3 \mathrm{~b})$, the absence of diffraction peaks indicates that the material is amorphous. At $1273 \mathrm{~K}(3 \mathrm{c})$ the process of sample crystallization is observed. Increasing the temperature up to $1573 \mathrm{~K}$, the crystallization process is completed. The peak at $30.3(100)$, where the number in parenthesis is the relative intensity, is assigned to $\mathrm{Sb}_{2} \mathrm{O}_{5}$ because $\mathrm{ZrO}_{2}$ crystalline species (Table 3 ) does not show any peaks in this region. The most intense peak of $\mathrm{ZrO}_{2}$ is observed at $28.2^{0}$ (100), and in $\mathrm{SiO}_{2} / \mathrm{ZrO}_{2} / \mathrm{Sb}_{2} \mathrm{O}_{5}$ it appears at 28.3 (60). For the bulk phase, a standard antimony oxide peak is observed at 28.7 (20) but, in this case, its intensity is considerably lower. The diffraction peak of antimony oxide (Figure $3 \mathrm{e}$ ) at $14.8^{0}$, despite its intensity, is not observed in Figure $3 \mathrm{~d}$. The peak observed at $21.9^{\circ}$ in Figure $3 \mathrm{e}$ is due to the $\mathrm{SiO}_{2}$ as cristoballite (see Table 3), indicating that this phase is segregated for samples heat treated at $1573 \mathrm{~K}$. The peak at $60.2^{\circ}(40)$ in Figure $3 \mathrm{~d}$ is not observed in antimony oxide or in zirconium oxide phases (see Table 3). This last peak is unequivocally assigned to a different

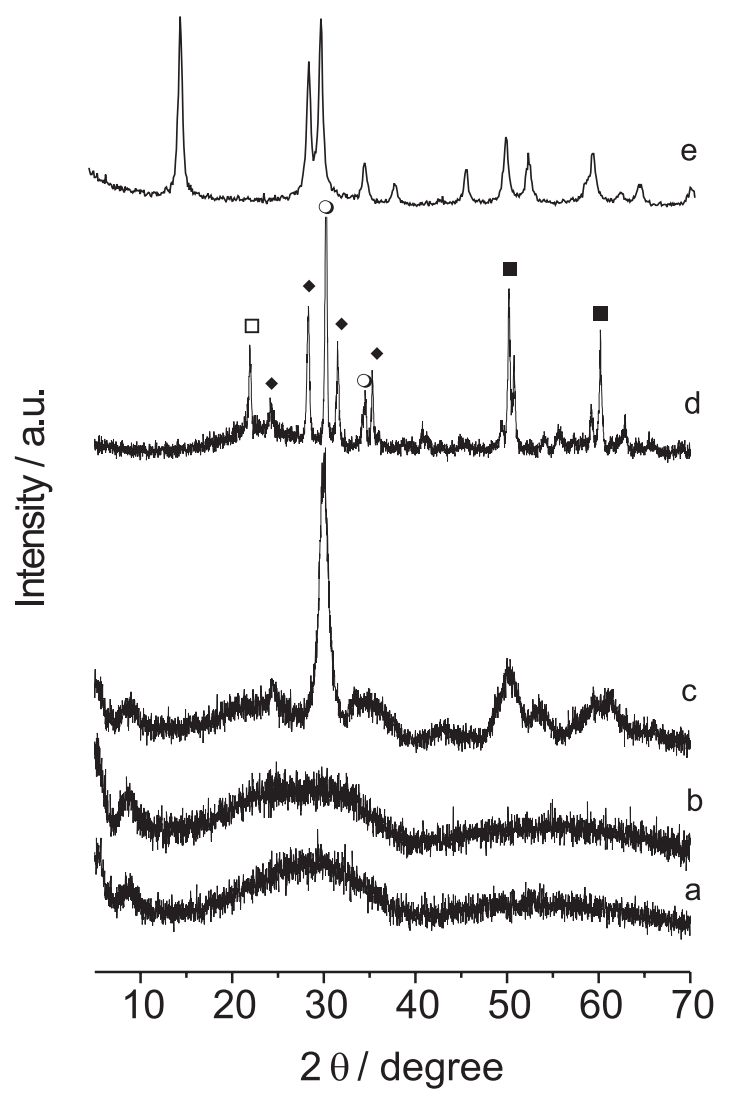

Figure 3. XRD patterns for $\mathrm{SiO}_{2} / \mathrm{ZrO}_{2} / \mathrm{Sb}_{2} \mathrm{O}_{5}$ (II) heat treated at various temperatures: a) $773 \mathrm{~K}$, b) $1023 \mathrm{~K}$, c) $1273 \mathrm{~K}$, d) $1573 \mathrm{~K}$ ( $\square$ $\mathrm{SiO}_{2} ; \mathrm{ZrO}_{2} ; \mathrm{O} \mathrm{Sb}_{2} \mathrm{O}_{5} ; \mathbf{a}$ zirconium oxide-antimonium oxide new phase) and e) for $\mathrm{Sb}_{2} \mathrm{O}_{5}$ crystalline phase. phase, presumably formed by the reaction between $\mathrm{Sb}(\mathrm{V})$ and $\mathrm{Zr}(\mathrm{IV})$ on the matrix surface, but unfortunately, the structure of this phase is unknown. ${ }^{24}$

\section{Acid properties}

Figure 4 shows the IR spectra of pyridine adsorbed on $\mathrm{SiO}_{2} / \mathrm{ZrO}_{2} / \mathrm{Sb}_{2} \mathrm{O}_{5}(\mathrm{I})$ heat treated at various temperatures from 323 to $573 \mathrm{~K}$. Four vibrational modes assignable to the pyridine molecule are shown. The absorption band at $1445 \mathrm{~cm}^{-1}$, whose intensity changes for the sample heat treated at higher temperatures and practically disappears at $573 \mathrm{~K}$, is assigned to the $19 \mathrm{~b}$ mode of pyridine, attached by hydrogen bonds to unreacted $\equiv \mathrm{SiOH}$ groups. ${ }^{3,25}$ The band at $1457 \mathrm{~cm}^{-1}$, which appears as a shoulder at $373 \mathrm{~K}$ and is clearly observable for sample heated at $573 \mathrm{~K}$, is assigned to the pyridine $19 \mathrm{~b}$ mode bonded to a Lewis acid site (LAS) ${ }^{26}$ This LAS is mainly due to the highly dispersed coordinatively unsaturated $\mathrm{Sb}(\mathrm{V})$ on the surface. For sample $\mathrm{SiO}_{2} / \mathrm{ZrO}_{2} / \mathrm{Sb}_{2} \mathrm{O}_{5}(\mathrm{I})$, the XPS technique shows that atomic ratio $\mathrm{Sb} / \mathrm{Zr} \sim 3$ (calculated from data of Table 2) and taking into account the depth the technique can probe (about $30 \mathrm{~nm}$ in the present case), we can consider that at the matrix surface the concentration of antimony is nearly three times higher compared to zirconium. For chemical evidence that this assumption is correct, Alizarine Red S (AlizRS) dye was adsorbed from aqueous solution onto $\mathrm{SiO}_{2} / \mathrm{ZrO}_{2}(\mathrm{I})$ and $\mathrm{SiO}_{2} / \mathrm{ZrO}_{2} / \mathrm{Sb}_{2} \mathrm{O}_{5}$ (I) surfaces (Figure 5). It is well known that this reagent reacts with hydrated $\mathrm{ZrO}_{2}$

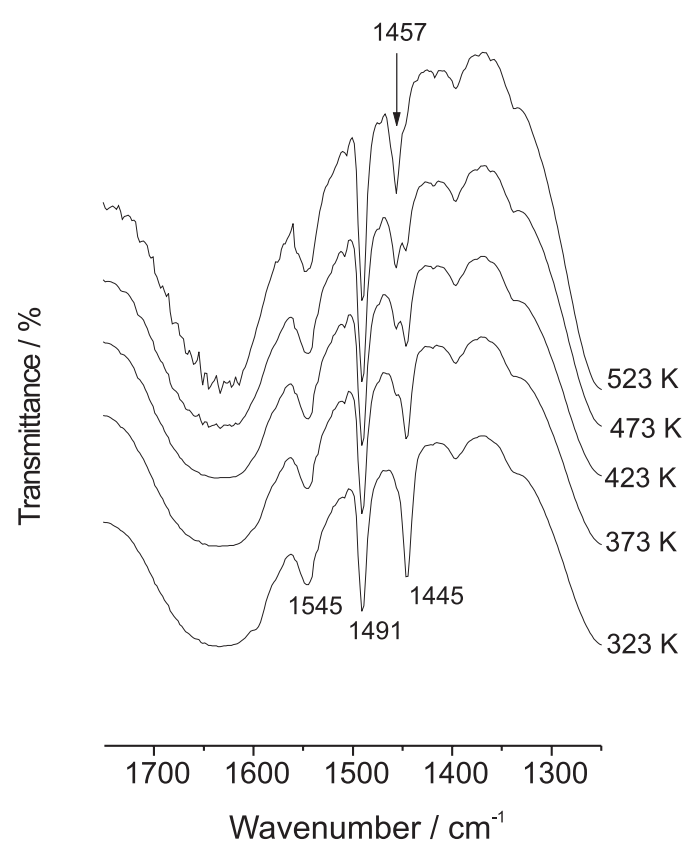

Figure 4. FT IR spectra of pyridine molecules adsorbed on $\mathrm{SiO}_{2} /$ $\mathrm{ZrO}_{2} / \mathrm{Sb}_{2} \mathrm{O}_{5}$ (I) heat treated at various temperatures. 


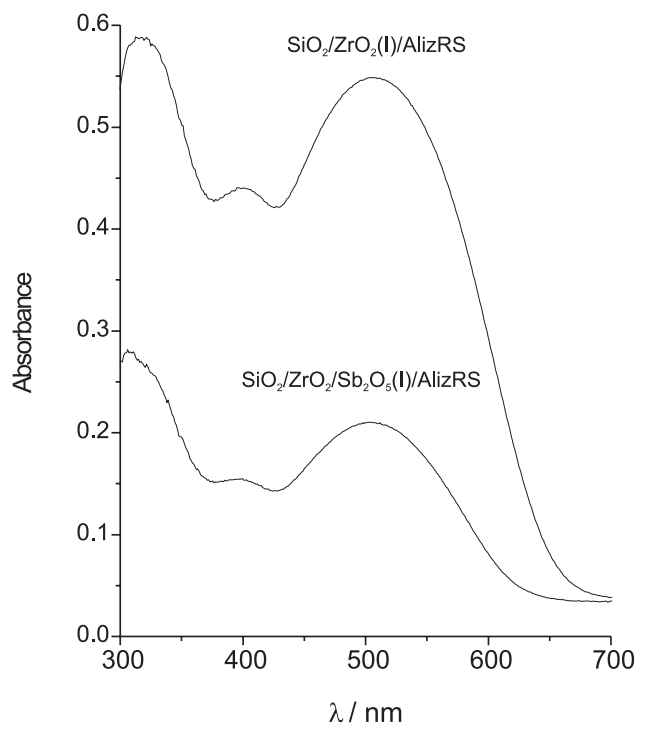

Figure 5. UV-vis DRS of Alizarin Red $\mathrm{S}$ adsorbed on $\mathrm{SiO}_{2} / \mathrm{ZrO}_{2}(\mathrm{I})$ and $\mathrm{SiO}_{2} / \mathrm{ZrO}_{2} / \mathrm{Sb}_{2} \mathrm{O}_{5}$ (I).

forming a $1: 1 \mathrm{Zr} /$ AlizRS complex whose maximum is observed as a broad band at about $500 \mathrm{~nm}$ (it is important to mention that $\mathrm{Sb}(\mathrm{V})$ and $\mathrm{SiO}_{2}$ do not react with AlizRS). ${ }^{27}$ The intensity of this band is considerably reduced, about $1 / 3$ for $\mathrm{SiO}_{2} / \mathrm{ZrO}_{2} / \mathrm{Sb}_{2} \mathrm{O}_{5}(\mathrm{I})$ in comparison with $\mathrm{SiO}_{2} / \mathrm{ZrO}_{2}(\mathrm{I})$. As the bulk $\mathrm{Sb}_{2} \mathrm{O}_{5}$ and $\mathrm{SiO}_{2}$ do not present $\mathrm{LAS}^{3,28}$ the band at $1457 \mathrm{~cm}^{-1}$ in Figure 4 is mainly due to LAS on coordenatively unsaturated $\mathrm{Sb}(\mathrm{V})$ on the $\mathrm{SiO}_{2} / \mathrm{ZrO}_{2} /$ $\mathrm{Sb}_{2} \mathrm{O}_{5}(\mathrm{I})$ surface.

The band observed at $1491 \mathrm{~cm}^{-1}$ is the pyridine 19a mode and, practically, does not shift when sorbed in different sites. ${ }^{29}$ The band observed at $1545 \mathrm{~cm}^{-1}$ is due to the $19 \mathrm{~b}$ mode of the pyridinium ion adsorbed on Brpnsted acid sites (BAS). ${ }^{24,30}$ It is very important to observe that the band intensity of this mode remains unchanged even for a sample treated at $573 \mathrm{~K}$. For bulk $\mathrm{Sb}_{2} \mathrm{O}_{5}$, this band is not observed for samples heat treated at this temperature, because the solid easily dehydrates and the BAS disappear.

\section{Conclusions}

$\mathrm{SiO}_{2} / \mathrm{ZrO}_{2}$ mixed oxide obtained by a sol-gel processing method adsorbs $\mathrm{Sb}(\mathrm{V})$ from acid solution forming a phase, not characterized, on the matrix surface. The materials obtained, $\mathrm{SiO}_{2} / \mathrm{ZrO}_{2} / \mathrm{Sb}_{2} \mathrm{O}_{5}$, have high surface areas, 590 and $440 \mathrm{~m}^{2} \mathrm{~g}^{-1}$ for the samples with lower and higher antimony contents, respectively. The Bronsted acid sites are thermally very stable, being observed for samples heated up to $573 \mathrm{~K}$. This thermal stability results from the low surface density, $\delta=\mathrm{N}_{\mathrm{o}} \mathrm{xN} / \mathrm{S}_{\mathrm{BET}}$, where $\mathrm{N}_{\mathrm{o}}$ and $\mathrm{N}$ are the amount of the zirconium-antimony oxide phase and Avogadro's number, respectively. Assuming that zirconiumantimony particles are homogeneously dispersed on the matrix the average inter-atomic distance, $l_{i j}$, can be estimated $^{23}$ by applying the equation $l_{i j}=(1 / \delta)^{1 / 2}$. The estimated values are $c a .1 .2$ and $0.7 \mathrm{~nm}$ for $\mathrm{SiO}_{2} / \mathrm{ZrO}_{2} /$ $\mathrm{Sb}_{2} \mathrm{O}_{5}(\mathrm{I})$ and $\mathrm{SiO}_{2} / \mathrm{ZrO}_{2} / \mathrm{Sb}_{2} \mathrm{O}_{5}(\mathrm{II})$, respectively. With these low surface densities of the zironium-antimony oxide particles on the matrix surface, the tendency of collapse into larger ones, with intermolecular loss of water and, consequently, reduction of the BAS and LAS on the surface, is minimized. ${ }^{19}$

\section{Acknowledgements}

G.Z. is indebted to Fundação de Amparo a Pesquisa do Estado de São Paulo (FAPESP), Brazil, for a Post-Doctoral fellowship and Y.G. to FAPESP and FINEP/Pronex for financial support. English revision by Prof. Carol H. Collins is also acknowledged.

\section{References}

1. Abe M.; Ito T.; Bull. Chem. Soc. Jpn. 1968, 41, 2366.

2. Abe M.; Chitrakar R.; Tsuji M.; Fukumoto K.; Solv. Extr. Ion Exch. 1985, 3, 149.

3. Benvenutti, E.V.; Gushikem, Y.; Davanzo, C.U.; C. de Castro, Sandra; Torriani, I.L.; J. Chem. Soc., Faraday Trans. 1992, 88, 3193.

4. Gonçalves, J.E.; Gushikem, Y.; de Castro, S.C.; J. Non-Cryst. Solids 1999, 260, 125.

5. Salvado, M.J.M.; Margaça, F.M.A.; Teixeira, J.; J. Non-Cryst. Solids 1993, 163, 115.

6. De Lange, R.S.A.; Kleizer, J.H.A.; Burgraaf,; A.J.; J. NonCryst. Solids 1995, 191, 1.

7. Haereid, S.; Dahle, M.; Lima, S.; Einarsud, M.A.; J. NonCryst. Solids 1995, 186, 96.

8. Alfaya, A.A.S.; Gushikem Y.; J. Colloid Interface Sci. 1999, 209, 428.

9. Turner, M.R.; Duguet, E.; Labrugere, C.; Surf. Interface Anal. 1997, 25, 917.

10. Toba, M.; Mizukami, F.; Niva, S.; Sato, T.; Maeda, K.; Annila, A.; Komppa, V.; J. Mol. Catal. 1994 ,94, 85.

11. Anderson J.A.; Fergusson C.; Rodriges-Ramos, I.; GuerreroRuiz, A.; J.Catal. 2000, 192, 344.

12. de Monte, F.; Larsen, W.; Mackenzie, J.D.; J. Am. Ceram. Soc. 2000, 83, 1506.

13. Pickup, D.M.; Mountjoy G.; Wallidge, G.W.; Newport, R.J.; Smith, M.E.; Phys. Chem. Chem. Phys. 1999, 1, 2527.

14. Alfaya, A.A.S.; Gushikem, Y.; de Castro, S.C.; Micr. Mesop. Mater. 2000, 39, 57. 
15. Scofield, J.H.; J. Electron Spectrosc. Relat. Phenom. 1976, 8, 129.

16. Gao X.; Fierro, J.L.G. ; Wachs, I.E.; Langmuir 1999,15, 3169.

17. Moon, S.C.; Fujino, M.; Yamashita H.; Anpo, M.; J. Phys. Chem. B 1997, 101, 369.

18. Handbook of Photoelectron Spectroscopy; Perkin-Elmer, Eden Praine, 1992

19. Alberti, G.; Costantino, U.; Marletta, G.; Puglisi, O.; Pignataro; S.; J. Inorg. Nucl. Chem. 1981, 43, 3329.

20. Morgan, W.E.; Stec, W.J.; Van Wazer, J.R.; Inorg. Chem. 1973, 12, 953.

21. Goodhew P.J.; Humphreys, F.J.; Electron Microscopy and Analysis, $2^{\text {nd }}$ ed., Taylor and Francis: London, 1992.

22. Powder Diffraction File Search Manual, The Joint Committee on Powder Diffraction Standards, Swarthmore, USA, 1997; ${ }^{a}$ file 39-1425; bfile 37-1484; ' file 33-0111.
23. Denofre, S.; Gushikem, Y.; de Castro, S.C.; Kawano, Y.; J. Chem. Soc., Faraday Trans. 1993, 89, 1057.

24. Bhattacharyya, D.K.; Dutta, N.C.; J. Nucl. Sci. Technol. 1991, 28, 1014.

25. Parry, E.P.; J. Catal. 1963, 2, 371.

26. Morterra, C.; Cerrato, G.; Langmuir 1990, 6, 1810.

27. Zittel, H.E.; Florence, T. M.; Anal. Chem. 1967, 39, 320.

28. Benvenutti, E.V., Gushikem, Y.; Davanzo, C.U.; Appl. Spectrosc. 1992, 46, 1474.

29. Connel, G.; Dumesic, J.A.; J. Catal. 1987, 105, 285.

30. Lefrancois, M.; Malbois, G.; J. Catal. 1971, 20, 350.

Received: July 4, 2001

Published on the web: August 23, 2002

FAPESP helped in meeting the publication costs of this article. 